\title{
GROWTH AND STRUCTURE OF ITALIAN ALDER (Alnus cordata /Loisel./ Duby) LINEAR PLANTATION AT AGE 11 AND 16 YEARS AT FRUŠKA GORA (SERBIA)
}

\author{
RAST I STRUKTURA LINIJSKOG ZASADA TALIJANSKE \\ JOHE (Alnus cordata /Loisel./ Duby) U DOBI 11 I 16 GODINA \\ NA FRUŠKOJ GORI (SRBIJA)
}

Martin BOBINAC1, Siniša ANDRAŠEV², Nikola ŠUŠIĆ ${ }^{3}$, Andrijana BAUER-ŽIVKOVIĆ4 ${ }^{4}$ Đura JORGIĆ 5

\begin{abstract}
SUMIMARY
Growth and structure of Italian alder (Alnus cordata /Loisel/ Duby) trees were analyzed in a linear plantation established by planting two-year-old seedlings at Fruška Gora (Serbia). The aim of this paper is to point out the growth characteristics and the structure of the Italian alder linear plantation at age 11 and 16 years and contribute to the knowledge of adaptive and productive potential of the species in the available plantation in Serbia.

The spacing between the trees was $7 \mathrm{~m}$ (200 trees per hectare). The plantation is located on anthropogenically changed pedunculate oak and hornbeam site at $125 \mathrm{~m}$ above sea level. On the basis of 35 measured trees at age 11 and 16 years, the top height was 15 and $21 \mathrm{~m}$, and the Lorey's mean height 13.4 and $19.5 \mathrm{~m}$. The dominant diameter was $32.4 \mathrm{~cm}$ at age 11 and $59.4 \mathrm{~cm}$ at age 16 years. The mean quadratic diameter was 25.1 and $47 \mathrm{~cm}$. The productivity of the plantation is high. At age 11 years, the basal area was $9.9 \mathrm{~m}^{2} \cdot \mathrm{ha}^{-1}$, and the standing volume $107.2 \mathrm{~m}^{3} \cdot \mathrm{ha}^{-1}$ while at age 16 years, it was $34.7 \mathrm{~m}^{2} \cdot \mathrm{ha}^{-1}$ and $305.1 \mathrm{~m}^{3} \cdot \mathrm{ha}^{-1}$, respectively.

In the period from 11 to 16 years of age, the periodic annual increment in diameter was $4.4 \mathrm{~cm} \cdot \mathrm{year}^{-1}$, height 1.22 $\mathrm{m} \cdot \mathrm{year}^{-1}$, and in basal area and volume $4.9 \mathrm{~m}^{2} \cdot \mathrm{ha}^{-1} \cdot \mathrm{year}^{-1}$ and $39.6 \mathrm{~m}^{3} \cdot \mathrm{ha}^{-1} \cdot \mathrm{year}^{-1}$, respectively, pointing to fast growth of Italian alder.

Despite the limits due to a small sample and the fact that the linear plantation was analyzed, we generalise the following conclusion: the measured growth characteristics at age 11 and 16 years of Italian alder trees show that the species can grow fast and could be usable in similar areas.
\end{abstract}

KEY WORDS: Alnus cordata (Loisel) Duby, introduction, diameter and height distribution, growth increment.

\section{INTRODUCTION}

\section{UVOD}

The range of Italian alder (Alnus cordata /Loisel./ Duby) is small. It is found in Italy in the southern Apennines, and mountains of northeastern Corsica in France. The altitudinal range is from 200 to $1600 \mathrm{~m}$ (Ducci and Tani 2009). In Italy, the species is considered to be a very important Noble Hardwood (Turok et al., 1996). It was introduced to

\footnotetext{
1 Dr Martin Bobinac, Full Professor, University of Belgrade, Faculty of Forestry, Kneza Višeslava 1, 11030 Belgrade, Serbia, martin.bobinac@sfb.bg.ac.rs, Corresponding author ${ }^{2}$ Dr Siniša Andrašev, senior research associate (andrasev@uns.ac.rs), University of Novi Sad, Institute of Lowland Forestry and Environment, Antona Čehova 13d, 21102 Novi Sad, Serbia

${ }^{3}$ MSc Nikola Šušić, Research Trainee, University of Belgrade, Institute for Multidisciplinary Research, Belgrade, Serbia (nikola.susic@imsi.rs)

${ }^{4}$ MSc Andrijana Bauer-Živković, JP „Vojvodinašume”, Forest Estate „,Sremska Mitrovica”, Serbia (andrijana9@gmail.com)

${ }^{5}$ Đura Jorgić, Graduate Forest Engineer, Šid, Serbia
} 
Belgium, Netherlands, Portugal, Spain and United Kingdom (Shaw et al., 2017), and recently in Chile (Loewe et al., 2013) and New Zealand (Praciak et al., 2013). The species is characterised by rapid growth (Ducci and Tani, 2009), and lives in symbiosis with nitrogen-fixing bacteria Actinomyces alni (Frankia alni) /Woronin 1866/ Von Tubeuf 1895/ (Benson et al., 2004) thus improving soil fertility (Chiti et al., 2007; Innangi et al., 2017). For this reason, it is recommended as ideal for afforestation and reforestation (Innangi et al., 2017). It was used in windbreak plantations where better results were observed compared to poplars and willows (Praciak et al., 2013). The species is used as ornamental since it is considered to be one of the most decorative Alnus species (Mitchell 1979; Krüssmann 1984). In Croatia, A. cordata is recorded as decorative tree species (Ettinger 1892; Vidaković 1986; Karavla 1994; Đurasović 1997). The first report of Italian alder in Serbia is from a linear plantation at Fruška Gora (Bobinac et al., 2015a).

Italian alder is a broadleaved tree species that can reach a height of more than $25 \mathrm{~m}$ in natural forests (Ducci and Tani 2009), or up to $28 \mathrm{~m}$ in favourable conditions (Shaw et al., 2017) with diameter at breast height of more than $65 \mathrm{~cm}$ (Ducci and Tani, 2009). The species can grow over $15 \mathrm{~m}$ high in 20 years (Mitchell 1979; Shaw et al., 2017). According to Clark et al. (2008), the species can grow over $5 \mathrm{~m}$ tall until the age of 6 years.

Compared to other Alnus species, the Italian alder is less dependent on permanent standing water (Shaw et al., 2017) and grows well on calcerous soil (Russel et al., 2007). Within its range, the species prefers damp soils, but can adapt to different soils and can even be found on dry sites in lowland areas or mountains (Burnie and Foulis, 2004; Shaw et al, 2017).

Italian alder can be managed both as high and coppice stands (Ducci and Tani, 2009; Praciak et al., 2013). According to Praciak et al. (2013), suggested rotation is $25-30$ years in coppice management. It is used as ancillary species in mixed plantations for timber production of high quality, and for biomass production (Caudullo and Mauri, 2016). Main tree species in mixed plantations supported by ancillary nitrogen-fixing species show higher diameter (Corazzesi et al., 2010; Bianchetto et al., 2013; Testaferri et al., 2019) and height increment (Corazzesi et al., 2010; Testaferri et al., 2019). In mixed plantations, Italian alder integrates well with Juglans regia (Tani et al., 2006; Cutini and Giannini, 2009) and pedunculate oak (Buresti and Frattegiani, 1992; Corazzesi et al., 2010; Battipaglia et al., 2017).

The aim of this paper is to point out the growth characteristics and the structure of the Italian alder linear plantation at age 11 and 16 years and contribute to the knowledge of adaptive and productive potential of the species in the available plantation in Serbia.

\section{MATERIALS AND METHODS MATERIJALI I METODE}

\section{Research object - Objekt istraživanja}

The research was conducted in the plantation of Italian alder established at the end of 2005 in Erdevik, National park "Fruška Gora" ( $\left.\varphi=45^{\circ} 07^{\prime} \mathrm{N}, \lambda=19^{\circ} 21^{\prime} \mathrm{E}\right)$. The seedlings used for the plantation were $1.5-2.0 \mathrm{~m}$ tall and two years old. The seedlings were produced from seed and donated by a forestry engineer, nurseryman and collector Đura Jorgić. The seeds were collected in the arboretum Lisičine (Croatia) where this species was previously recorded (Vidaković 1986). The plantation establishment was performed in the form of linear plantation - in some parts there was one, and in other two rows of seedlings with $7 \mathrm{~m}$ spacing between them (200 trees per hectare).

The plantation was established in the coastline of the reservoir Bruje at $125 \mathrm{~m}$ above sea level where zonal plant community is Carpino betuli-Quercetum roboris /Anić 59/ Rauš 1971 (Tomić 2013). The coastline is characterised by a pioneer shrub community of grey willow (Alliance: Salicion cinereae Th. Müller \& Görs 1958.).

The mean annual air temperature is $11.3^{\circ} \mathrm{C}$ (absolute minimum $-29.5^{\circ} \mathrm{C}$; absolute maximum $43.6^{\circ} \mathrm{C}$ ) according to weather station Sremska Mitrovica. Around $60 \%$ of the mean annual precipitation $(614.2 \mathrm{~mm})$ falls during the growing season (data from Republic Hydrometeorological Service of Serbia for the period 1981-2010, Source: http:// www.hidmet.gov.rs/).

\section{Measurements and data analysis of growth - Premjer i analiza podataka o rastu}

The sample used for the dendrometric measurements at age 11 and 16 years was comprised of 35 numbered trees. The trees were solitary until age of 8 years when branches of adjacent trees were touching. Tree vitality was assessed according to Visual Tree Assessment guide described by Mattheck and Breloer (1994). Diameter at breast height (DBH) was calculated from circumference of trees measured at breast height with accuracy $\pm 1 \mathrm{~mm}$. The total height was measured with Vertex III (Haglöf Sweden AB, Långsele, Sverige) with accuracy $\pm 0.1 \mathrm{~m}$. Basic descriptive statistics - arithmetic mean $\left(x^{-}\right)$, standard deviation $\left(s_{\mathrm{x}}\right)$, coefficient of variation $(\mathrm{CV})$, minimum (min), maximum (max), skewness and kurtosis - were calculated for every of the measured (diameter and height) and calculated growth characteristics (basal area, volume) as well as $\mathrm{h} / \mathrm{DBH}$ ratio and periodic annual increments (PAI) calculated as the difference between two successive growth element measurements of each tree divided by amount of years between measurements (Pretzsch, 2009).

On the basis of the collected data, the mean quadratic diameter $\left(\mathrm{d}_{\mathrm{g}}\right)$, the mean diameter of $20 \%$ thickest trees $\left(\mathrm{D}_{\text {dom }}\right)$, 
the Loray's mean height $\left(\mathrm{h}_{\mathrm{L}}\right)$ and the top height based on $20 \%$ thickest trees $\left(\mathrm{H}_{\mathrm{dom}}\right)$ were calculated. The standing volume of the plantation was calculated using volume tables for black alder (Mirković 1975) with the analytical shape:

$$
\begin{aligned}
& V_{\text {bole }}=1.98087 \cdot\left(\frac{D B H}{100}\right)^{1.51338} \cdot h^{0.22385} \cdot 10^{0.05904}\left[\mathrm{~m}^{3}\right] \\
& V_{\text {branches }}=14.59 \cdot\left(\frac{h-2}{h}\right)^{2-5.25} \cdot\left(\frac{h-2}{h}\right)+3.45\left[\mathrm{~m}^{3}\right]
\end{aligned}
$$

The height curves were fitted using the function of Chapman-Richards. Power function was used to fit the relation between $\mathrm{h} / \mathrm{DBH}$ ratio and corresponding diameters at breast height. Linear function was used to fit the relation between the trees' PAI of growth characteristics and their initial values (at age 11 years).

\section{RESULTS}

\section{REZULTATI}

\section{Growth of the trees and the linear plantation - Rast stabala i zasada}

High values of mean diameters and heights were recorded in Italian alder linear plantation (Table 1). On the basis of the calculation that there are 200 trees per hectare, the basal area was close to $10 \mathrm{~m}^{2} \cdot \mathrm{ha}^{-1}$ at age 11 years and volume was slightly over $100 \mathrm{~m}^{3} \cdot \mathrm{ha}^{-1}$. At age 16 years, basal area was close to $35 \mathrm{~m}^{2} \cdot \mathrm{ha}^{-1}$ and volume slightly over $300 \mathrm{~m}^{3} \cdot \mathrm{ha}^{-1}$.

The diameter distributions are unimodal in both measurements. Most of the trees are in the diameter class $22.5 \mathrm{~cm}$ (age 11 years) and $47.5 \mathrm{~cm}$ (age 16 years) - Figure 1. DBH arithmetic mean is in the modal diameter class in both of the measurements. The DBHs at age 11 years were within the range of $13-35 \mathrm{~cm}$ with the coefficient of variation of $23 \%$. At age of 16 years, the DBHs were within the range of $25-64 \mathrm{~cm}$ with the coefficient of variation reduced by $1.4 \%$ since the age of 11 years while the standard deviation increased by twofold.

In both of the measurements, the diameter distributions were characterised by weak left skewness and platykurtic shape (Table 2).

The height range was between 10.3 and $16.2 \mathrm{~m}$ at age 11 years and 14.5 and $22.9 \mathrm{~m}$ at age 16 years. As trees age, the standard deviation of the height distribution slowly increases while coefficient of variation decreases. The distribution shape changes with age as well. At age 11 years, the distribution shape is skewed to the right and platykurtic

Table 1. Growth of the trees in the linear plantation at age 11 and 16 years.

Tablica 1. Rast stabala u zasadu u starosti 11 i 16 godina.

$\begin{array}{ccccccccc}\begin{array}{c}\text { Age } \\ \text { Starost }\end{array} & \mathrm{H}_{\text {dom }} & \mathrm{h}_{\mathrm{L}} & \mathrm{D}_{\text {dom }} & \mathrm{d}_{\mathrm{g}} & \mathrm{N} & \mathrm{G} & \mathrm{V} \\ \begin{array}{c}\text { [year] } \\ \text { [godina] }\end{array} & {[\mathrm{m}]} & {[\mathrm{m}]} & {[\mathrm{cm}]} & {[\mathrm{cm}]} & \begin{array}{c}\text { [trees] } \\ \text { [stabala] }\end{array} & {\left[\mathrm{m}^{2} \cdot \mathrm{ha}^{-1}\right]} & {\left[\mathrm{m}^{3} \cdot \mathrm{ha}^{-1}\right]} \\ 11 & 15.0 & 13.4 & 32.4 & 25.1 & 200 & 9.89 & 107.2 \\ 16 & 21.0 & 19.5 & 59.4 & 47.0 & 200 & 34.68 & 305.1\end{array}$

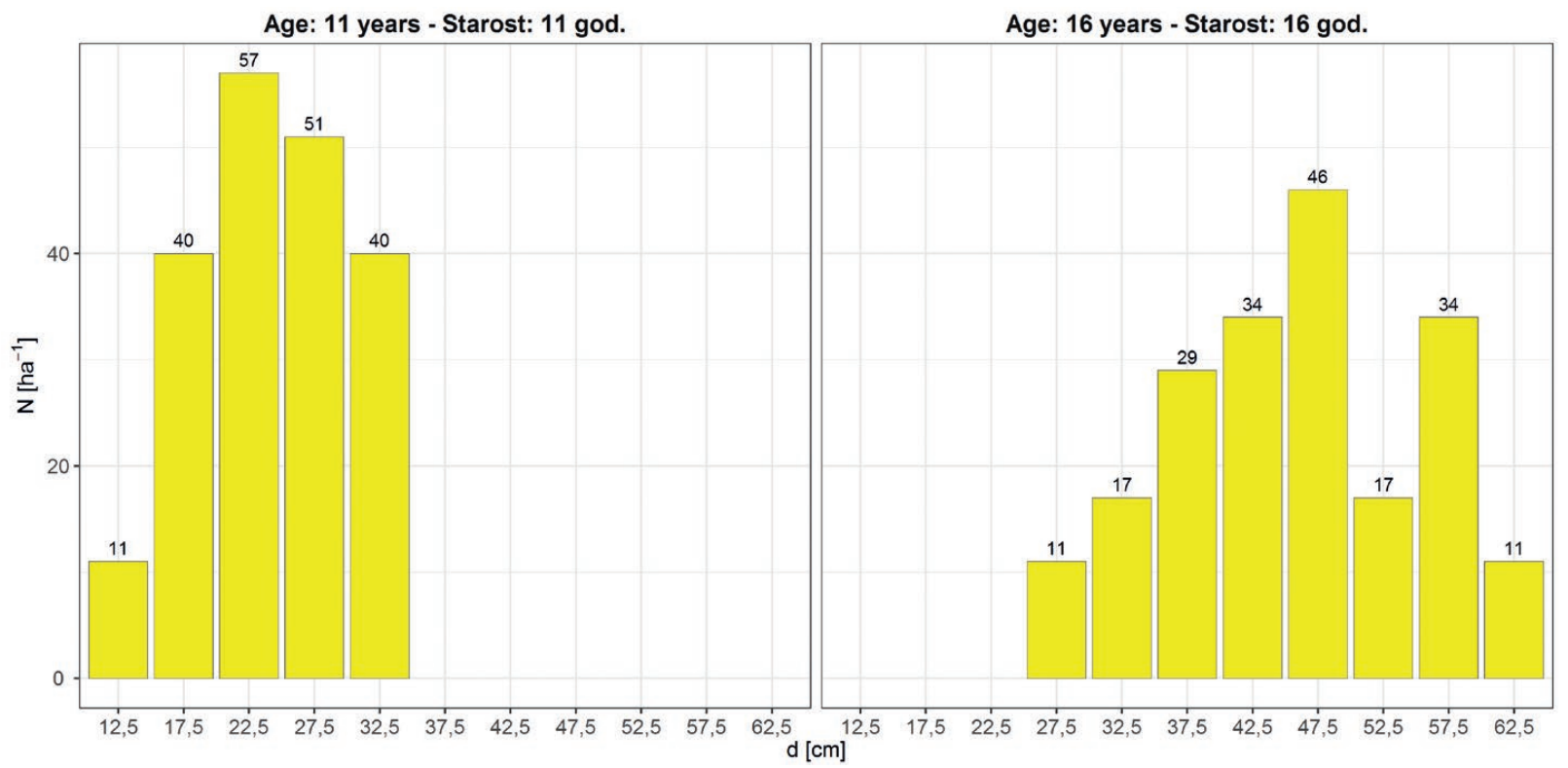

Figure 1. Diameter distribution of the trees in the linear plantation at age 11 and 16 years.

Slika 1. Debljinska struktura stabala u zasadu u starosti 11 i 16 godina. 
Table 2. The height and diameter structure of the trees at age 11 and 16 years.

Tablica 2. Struktura stabala po debljini i visini u starosti 11 i 16 godina.

\begin{tabular}{ccccccccccc} 
Growth characteristic & Age & & $\bar{x}$ & $\min$ & $\max$ & $\mathrm{s}_{\mathrm{d}}$ & CV & skew & kurt \\
Značajka rasta & Starost & $\mathrm{n}$ & & & & & & & & \\
\hline Diameter $-\mathrm{d}_{1,3}[\mathrm{~cm}]$ & 11 & 35 & 24.5 & 13.0 & 34.9 & 5.62 & 23.0 & -0.065 & -0.611 \\
Promjer $-d_{1,3}[\mathrm{~cm}]$ & 16 & 35 & 46.0 & 25.3 & 63.7 & 9.91 & 21.6 & -0.117 & -0.814 \\
& 11 & 35 & 12.8 & 10.3 & 16.2 & 1.77 & 13.8 & 0.307 & -1.001 \\
Height $-\mathrm{h}[\mathrm{m}]$ & 16 & 35 & 19.0 & 14.5 & 22.9 & 1.94 & 10.2 & -0.120 & -0.181 \\
Visina $-\mathrm{h}[\mathrm{m}]$ & & & & & & &
\end{tabular}

Age: 11 years - Starost: 11 god.

Age: 16 years - Starost: 16 god.

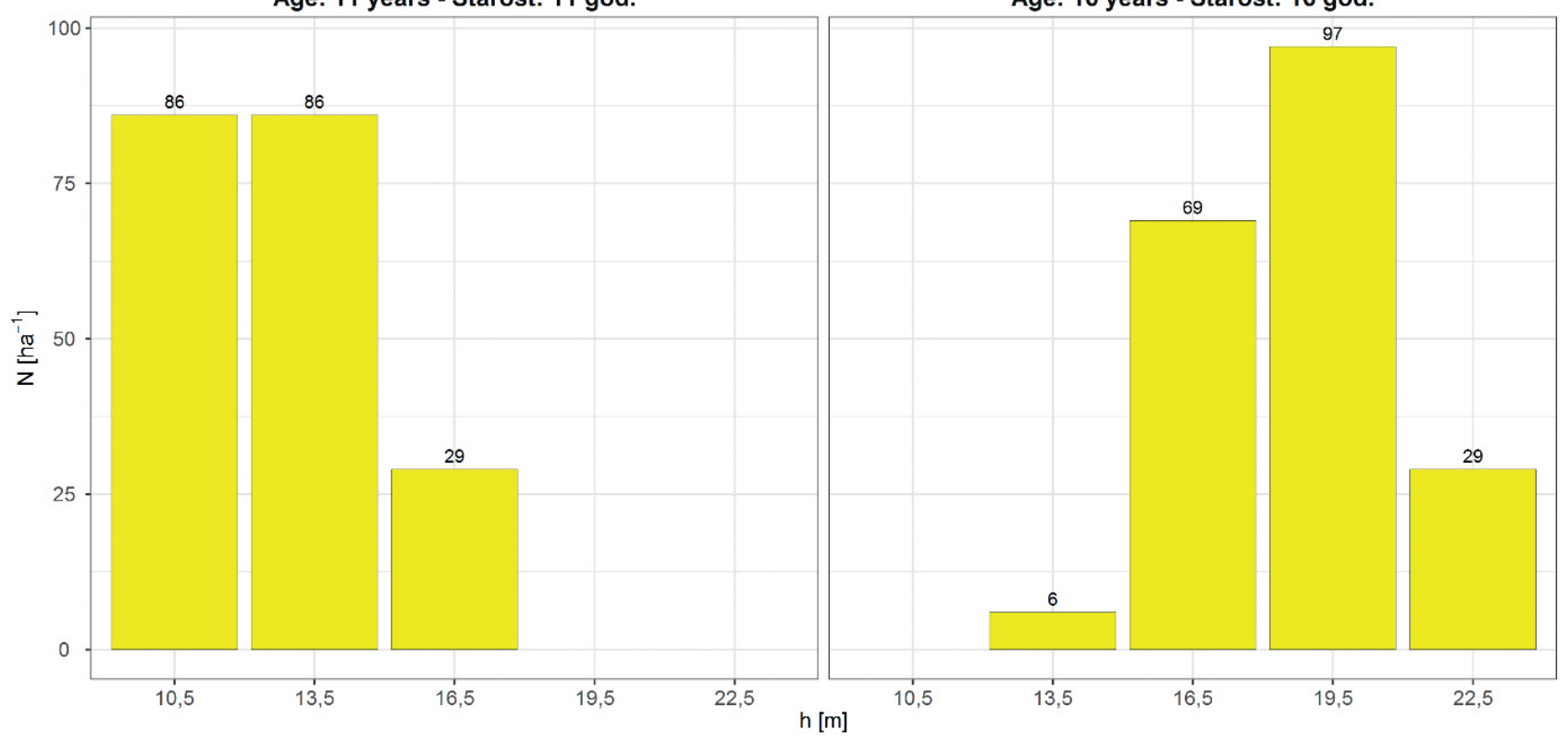

Figure 2. Height distribution of the trees in the linear plantation at age 11 and 16 years.

Slika 2. Visinska struktura stabala u zasadu u starosti 11 i 16 godina.

and at age 16 years it is skewed to the left and slightly platycurtic (Table 2).

Height distribution, expressed by grouping heights into 3 $\mathrm{m}$ wide height classes has a reverse J-shaped distribution at age 11 years and normal unimodal shape at age 16 years (Figure 2).

\section{Height curves and h/DBH ratio - Visinske krivulje i stupanj vitkosti}

Obtained measure of fit of the height curves show that 55\% of the variability of tree heights can be attributed to their corresponding diameters at age 11 years. This relationship is less expressed at age 16 years (Table 3, Figure 3 ).

The slenderness coefficient expressed as h/DBH ratio points to static stability of the trees. At age 11 years, h/DBH ratio was 38-79 (54 on average) and 38-79 (43 on average) at age 16 years. Accordingly, as the h/DBH ratio decreases, its variability slightly increases and the distribution keeps its right assymetry as kurtosis shifts from platykurtic at age 11 to mesokurtic shape at age 16 years (Table 4).

The relationship between $\mathrm{h} / \mathrm{DBH}$ ratio and corresponding diameters at breast height has a reverse J-shaped distribution that was successfully fitted with power function (Figure 3).

Table 3. Model parameters and measures of fit of height curves.

Tablica 3. Parametri modela visinskih krivulja i njihova ocjena u starosti 11 i 16 godina.

\begin{tabular}{cccccc} 
Age & \multicolumn{1}{c}{ Model: } & & \multicolumn{3}{c}{$\begin{array}{c}\text { Measures of fit } \\
\text { Ocjena modela }\end{array}$} \\
Starost & $\mathrm{a}$ & $\mathrm{b}$ & $\mathrm{c}$ & $\mathrm{S}_{\mathrm{e}}[\mathrm{m}]$ & $\mathrm{R}^{2}$ \\
11 & 118.9969 & 0.000344 & 0.486983 & 1.184 & 0.550 \\
16 & 84.49238 & 0.000115 & 0.297155 & 1.548 & 0.362
\end{tabular}




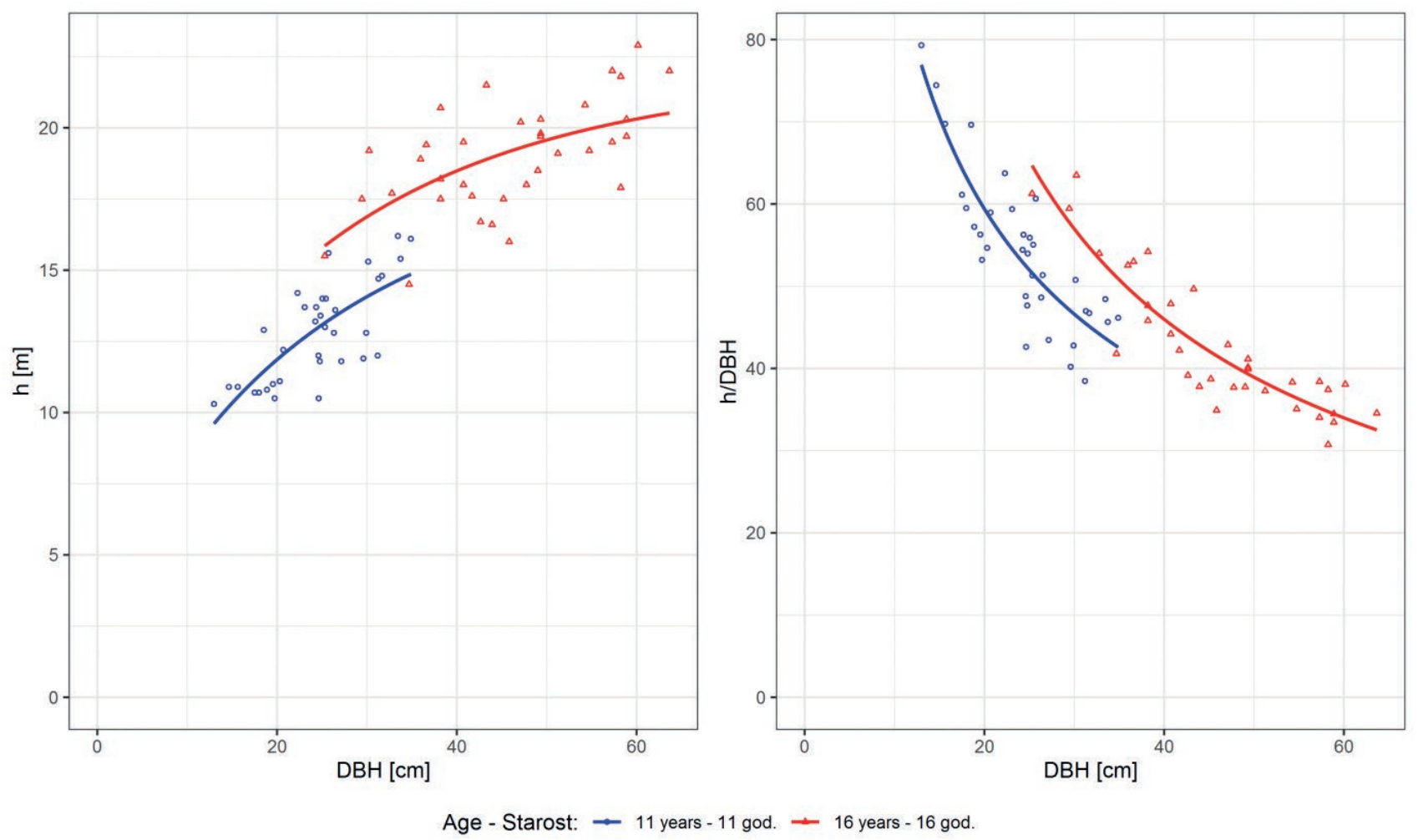

Figure 3. Height curves (left) and h/DBH ratio curves (right) in the plantation at age 11 and 16 years.

Slika 3. Visinske krivulje i krivulje ovisnosti stupnja vitkosti o prsnim promjerima u starosti zasada 11 i 16 godina.

Table 4. The structure of h/DBH ratio at age 11 and 16 years.

Tablica 4. Struktura stabala po stupnju vitkosti u starosti 11 i 16 godina.

\begin{tabular}{cccccccccc}
$\begin{array}{c}\text { Growth characteristic } \\
\text { Značajka rasta }\end{array}$ & $\begin{array}{c}\text { Age } \\
\text { Starost }\end{array}$ & $\mathrm{n}$ & $\bar{x}$ & $\min$ & $\max$ & $\mathrm{s}_{\mathrm{d}}$ & CV & skew & kurt \\
\hline h/DBH ratio & 11 & 35 & 54.1 & 38.5 & 79.3 & 9.45 & 17.5 & 0.765 & 0.557 \\
Stupanj vitkosti - h/DBH & 16 & 35 & 42.8 & 30.7 & 63.5 & 8.44 & 19.7 & 0.960 & 0.080
\end{tabular}

Most of the $\mathrm{h} / \mathrm{DBH}$ ratio variability (75\% at age 11 and $81 \%$ at age 16 years) can be attributed to the corresponding DBHs (Table 5).

\section{The increments of the trees and the linear plantation} - Prirast stabala i zasada

Tree vitality assessment showed that the trees are very vigorous (best score according to the classification of Mattheck and Breloer, 1994). The good vitality status of the trees and the plantation is confirmed by recorded increments (Table 6).
Distribution shapes of diameter and height PAI are different - diameter PAI is slightly skewed to the right and platykurtic while height PAI is skewed to the left and almost mesokurtic. The distribution shapes of basal area and volume PAI's are very similar and characterised by slight right asymmetry and platykurtic shape.From age 11 to 16 years, $\mathrm{h} / \mathrm{DBH}$ ratio has an annual average decrease of 2.25 , and the range of decrease is $0.68-4.10$ (Table 7).

The relationship between the trees' PAI (diameter) and their corresponding diameters at age 11 years is well described by a linear regression model where $50 \%$ of the variability

Table 5. Model parameters of h/DBH ratio depending on DBH of trees and measures of fit at age 11 and 16 years.

Tablica 5. Parametri modela stupnja vitkosti u ovisnosti od prsnih promjera stabala i njihova ocjena u starosti 11 i 16 godina.

\begin{tabular}{|c|c|c|c|c|}
\hline $\begin{array}{l}\text { Age } \\
\text { Starost }\end{array}$ & \multicolumn{2}{|c|}{ Model: } & \multicolumn{2}{|c|}{$\begin{array}{l}\text { Measures of fit } \\
\text { Ocjena modela }\end{array}$} \\
\hline 11 & 356.6646 & -0.59837 & 4.739 & 0.748 \\
\hline 16 & 718.9356 & -0.7454 & 3.662 & 0.812 \\
\hline
\end{tabular}


Table 6. PAl's of growth characteristics of the linear plantation at age 11 and 16 years.

Tablica 6. Prosječni tečajni godišnji prirast značajki rasta zasada u periodu od 11. do 16. godine.

\begin{tabular}{|c|c|c|c|c|c|c|}
\hline $\begin{array}{l}\text { Age } \\
\text { Starost }\end{array}$ & $\mathrm{i}_{\text {Hdom }}$ & $i_{h L}$ & $\mathrm{i}_{\text {Ddom }}$ & $\mathrm{i}_{\mathrm{dg}}$ & $I_{G}$ & V \\
\hline [year] [godina] & $\begin{array}{l}{\left[\mathrm{m} \cdot \text { year }^{-1}\right]} \\
{\left[\mathrm{m} \cdot \mathrm{god}^{-1}\right]}\end{array}$ & $\begin{array}{l}{\left[\mathrm{m} \cdot \text { year }^{-1}\right]} \\
{\left[\mathrm{m} \cdot \text { god }^{-1}\right]}\end{array}$ & $\begin{array}{l}{\left[\mathrm{cm} \cdot \text { year }^{-1}\right]} \\
{\left[\mathrm{cm} \cdot \text { god }^{-1}\right]}\end{array}$ & $\begin{array}{l}{\left[\mathrm{cm} \cdot \mathrm{year}^{-1}\right]} \\
{\left[\mathrm{cm} \cdot \text { god }^{-1}\right]}\end{array}$ & $\begin{array}{l}{\left[\mathrm{m}^{2} \cdot \mathrm{ha}^{-1} \cdot \mathrm{year}^{-1}\right]} \\
{\left[\mathrm{m}^{2} \cdot \mathrm{ha}^{-1} \cdot \mathrm{god}^{-1}\right]}\end{array}$ & $\begin{array}{l}{\left[\mathrm{m}^{3} \cdot \mathrm{ha}^{-1} \cdot \text { year }^{-1}\right]} \\
{\left[\mathrm{m}^{3} \cdot \mathrm{ha}^{-1} \cdot \text { god }^{-1}\right]}\end{array}$ \\
\hline $11-16$ & 1.20 & 1.22 & 5.4 & 4.4 & 4.96 & 39.57 \\
\hline
\end{tabular}

Table 7. The structure of trees' PAl's in the period 11-16 years.

Tablica 7. Deskriptivna statistika prosječnih tečajnih godišnjih prirasta stabala u razdoblju od 11. do 16. godine.

\begin{tabular}{|c|c|c|c|c|c|c|c|c|}
\hline $\begin{array}{c}\text { PAl's of growth characteristics } \\
\text { Prirast značajki rasta }\end{array}$ & $n$ & $\bar{x}$ & $\min$ & $\max$ & $\mathrm{S}_{\mathrm{d}}$ & CV & skew & kurt \\
\hline $\mathrm{i}_{\mathrm{d}}\left[\mathrm{cm} \cdot \mathrm{year}^{-1}\right]\left[\mathrm{cm}\right.$ god $\left.^{-1}\right]$ & 35 & 4.3 & 2.5 & 6.5 & 1.02 & 23.7 & 0.183 & -0.779 \\
\hline $\mathrm{i}_{\mathrm{h}}\left[\mathrm{m} \cdot\right.$ year $\left.^{-1}\right]\left[\mathrm{m} \cdot \mathrm{god}^{-1}\right]$ & 35 & 1.23 & 0.74 & 1.66 & 0.21 & 17.1 & -0.607 & -0.096 \\
\hline $\mathrm{i}_{\mathrm{g}}\left[\mathrm{cm}^{2} \cdot\right.$ year $\left.^{-1}\right]\left[\mathrm{cm}^{2} \cdot \mathrm{god}^{-1}\right]$ & 35 & 248 & 74 & 445 & 104.0 & 42.0 & 0.299 & -0.974 \\
\hline $\mathrm{i}_{v}\left[\mathrm{dm}^{3} \cdot\right.$ year $\left.^{-1}\right]\left[\mathrm{dm}^{3} \cdot \operatorname{god}^{-1}\right]$ & 35 & 198 & 77 & 322 & 67.1 & 33.9 & 0.206 & -0.991 \\
\hline $\begin{array}{l}\mathrm{h} / \mathrm{DBH} \text { development } \\
\text { razvoj } h / D B H\end{array}$ & 35 & -2.25 & -4.10 & -0.68 & 0.84 & 37.3 & -0.216 & -0.574 \\
\hline
\end{tabular}

Table 8. Model parameters of PAl's of growth characteristics in relation to the values at age 11 years.

Tablica 8. Parametri modela prosječnih tečajnih godišnjih prirasta značajki rasta od njihovih veličina u 11. godini.

\begin{tabular}{|c|c|c|c|c|c|c|}
\hline $\begin{array}{c}\text { PAl's of growth characteristics } \\
\text { Prirast značajki rasta }\end{array}$ & a & b & $\mathrm{R}^{2}$ & $\mathrm{~s}_{\mathrm{e}}$ & $\begin{array}{c}\text { t-value } \\
t \text {-vrijednost }\end{array}$ & $\begin{array}{c}\mathrm{p} \text {-value } \\
p \text {-vrijednost }\end{array}$ \\
\hline 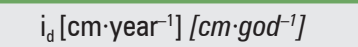 & 1.155875 & 0.128331 & 0.498 & 0.735 & 32.76 & 0.0000 \\
\hline $\mathrm{i}_{\mathrm{h}}\left[\mathrm{m} \cdot \mathrm{year}^{-1}\right]\left[{\left.\mathrm{m} \cdot \text { god }^{-1}\right]}^{-1}\right.$ & 1.436382 & -0.0159 & 0.017 & 0.214 & 0.58 & 0.4498 \\
\hline $\mathrm{i}_{\mathrm{g}}\left[\mathrm{cm}^{2} \cdot\right.$ year $\left.^{-1}\right]\left[\mathrm{cm}^{2} \cdot \mathrm{god}^{-1}\right]$ & 47.98623 & 0.404137 & 0.707 & 57.1 & 79.69 & 0.0000 \\
\hline $\mathrm{i}_{\mathrm{v}}\left[\mathrm{dm}^{3} \cdot\right.$ year $\left.^{-1}\right]\left[\mathrm{dm}^{3} \cdot \mathrm{god}^{-1}\right]$ & 45.23696 & 0.284652 & 0.683 & 38.4 & 71.02 & 0.0000 \\
\hline $\begin{array}{l}\text { h/DBH development } \\
\text { razvoj } h / D B H\end{array}$ & -0.10127 & -0.03979 & 0.201 & 0.760 & 8.33 & 0.0068 \\
\hline
\end{tabular}

can be attributed to the inital values of DBHs. The relationship between the trees' PAI (basal area and volume) and their corresponding basal area and volume values is even better described by the linear regression model where 68.3$70.7 \%$ of variability can be attributed to their initial values.

The trees' height PAI was not correlated to their initial values at age 11 years. However, the change of $\mathrm{h} / \mathrm{DBH}$ in the period from age 11-16 years has a pronounced negative linear trend - the trees with higher $\mathrm{h} / \mathrm{DBH}$ at age 11 years had a more pronounced decrease (Table 8 ).

\section{DISCUSSION AND CONCLUSIONS RASPRAVA I ZAKLJUČCI}

Italian alder was recently introduced to Serbia and reported in a linear plantation at Fruška Gora (Bobinac et al., 2015a). The first results of growing Italian alder in the linear plantation showed that the top height was $14.6 \mathrm{~m}$ and dominant diameter $32.1 \mathrm{~cm}$ at 11 years of age (Bobinac et al., 2015b). The values for $\mathrm{H}_{\mathrm{dom}}$ of $21.0 \mathrm{~m}, \mathrm{D}_{\mathrm{dom}}$ of $59.4 \mathrm{~cm}$ and height and diameter PAI $\left(1.2 \mathrm{~m} \cdot y \mathrm{yr}^{-1}\right.$ and $\left.5.4 \mathrm{~cm} \cdot \mathrm{year}^{-1}\right)$ at age 16 years show that the species grows rapidly. Basal area of nearly $35 \mathrm{~m}^{2} \cdot \mathrm{ha}^{-1}$ and volume of the plantation of over 300 $\mathrm{m}^{3} \cdot \mathrm{ha}^{-1}$ show that the plantation is very productive in researched conditions. Mean height of 9.9-10.4 m and mean DBH of 15.1-16.4 cm were measured in a pastoral system with A. cordata in New Zealand, at $3 \times 4 \mathrm{~m}$ spacing, at age 11 years (Devkota et al., 2009). According to Praciak et al. (2013), in the coppice stands (15-20 years rotation) of the most productive region of Italy, the highest recorded mean annual increment is $16 \mathrm{~m}^{3} \cdot \mathrm{ha}^{-1}\left(12-13 \mathrm{~m}^{3} \cdot \mathrm{ha}^{-1}\right.$ on average). However, a wide spacing of $7 \mathrm{~m}$ allows the trees to use large growing space, therefore more light and soil compared to different forms of plantations in the same spacing. The calculated volume and volume PAI are thus only approximate, therefore representing the potential of the species (Table 1 and 6). The trees have large leaf area due to crown length. In this plantation, the leaves keep green colour until the fall (end of November), or even until the middle of December in some years (Figure 4) so this trait represent an asset for high increment values at $7 \mathrm{~m}$ spacing. The long retention of leaves, until the November or December was described by Praciak et al. (2013) as well.

Vitality assessment and growth characteristics of trees at age 11 and 16 years in the plantation show that the species is characterised by rapid growth, similar to poplars. In a 


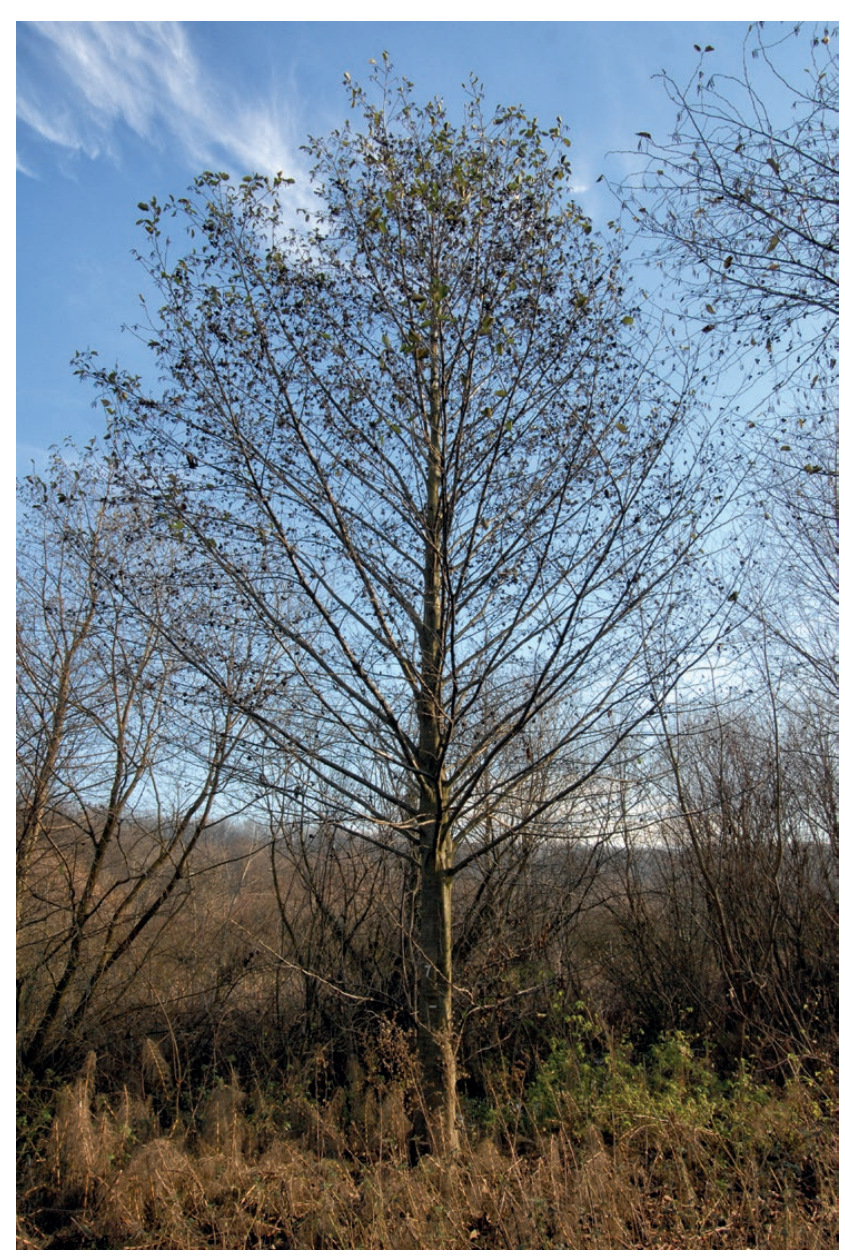

Figure 4. Leaf-fall phenophase of Italian alder (Alnus cordata /Loisel/ Duby) in the linear plantation in the area of Erdevik: 14/12/2014 (Photo: N. Stanković).

Slika 4. Fenofaza opadanja listova talijanske johe (Alnus cordata /Loisel/ Duby) u linijskom zasadu na području Erdevika: 14.12.2014. (Foto: N. Stanković).

two-row linear plantation of cl. I-214 at age 10 years, Marković and Živanov (1980) recorded diameters of $30-40 \mathrm{~cm}$, heights of 20-25 m and volume of $519 \mathrm{~m}^{3} \cdot \mathrm{ha}^{-1}$.

The Italian alder trees in the plantation have monopodial growth, conical bole axis and low-hanging branches due to weak competition for growing space. Slenderness coefficient, as the bole form indicator (Pretzsch 2009), decreases with trees age. At age 11 years, slenderness coefficient was 54 on average and 43 at age 16 years. Italian alder has fragile wood so tip breakages were recorded on some of the trees that quickly regenerated. If high density plantations are to be established, and thinnings prescribed, optimal spacing as well as the possibility of mixed species plantations should be investigated first, as the species is prone to branching. In high density plantations, heavy and frequent thinnings are recommended because of the fast growth of Italian alder (Praciak et al., 2013).

In the researched area, the maturation and pollen dispersal of male flowers of Italian alder occurs mostly at the end of
January or the beginning of February, and is recorded on some of the trees at the end of December (Bobinac et al., 2015a). Italian alder is a nearly-flowering species, and in context of climate change could be important for beekeping in the area, together with common hazel (Corylus avellana L.), that is more widely grown in plantations.

Despite the limits due to small sample and the fact that the linear plantation was analyzed, we generalise the following conclusion: the measured growth characteristics at age 11 and 16 years of Italian alder trees show that the species can grow fast and could be usable in Serbia - as a fast-growing tree species in plantations or as decorative in urban areas.

\section{ACKNOWLEDGEMENT ZAHVALA}

This study was supported by the Ministry of Education, Science and Technological Development, Republic of Serbia [Project No: 451-03-68/2020-14/200197; 451-03-68/2020$14 / 200053$ and 451-02-68/2020/14/200169].

\section{REFERENCES}

\section{LITERATURA}

- Battipaglia, G., F. Pelleri, F. Lombardi, S. Altieri, A. Vitone, E. Conte, R. Tognetti, 2017: Effects of associating Quercus robur L. and Alnus cordata Loisel. on plantation productivity and water use efficiency. Forest Ecology and Management 391: 106.-114.

- Benson, D.R., B.D. Vanden Heuvel, D. Potter, 2004: Actinorhizal symbioses: diversity and biogeography. In: Gillings M., Holmes A. (eds.): Plant Microbiology. Garland Science/BIOS Scientific, London/New York: 97.-128.

- Bianchetto, E., A. Vitone, C. Bidini, F. Pelleri, 2013: Effetto di differenti tipologie di consociazione sull'accrescimento e sulla qualità del noce comune (Juglans regia L.) in un impianto di arboricoltura da legno nell'Italia centrale. Ann Silvic Res 37(1): 38. -44 .

- Bobinac, M., S. Andrašev, M. Perović,A. Bauer-Živković, Đ. Jorgić, 2015a: Italian alder (Alnus cordata /Loisel./ Duby) — new species for allochthonous dendroflora of Serbia. Glasnik Šumarskog fakulteta 111: 21.-36., Beograd

- Bobinac, M., S. Andrašev, M. Perović, A. Bauer-Živković, Đ. Jorgić, 2015b: Growth elements of Italian Alder (Alnus cordata /Loisel./ Duby) trees - potentially applicable species in Serbia. In: V. Ivetić, D. Stanković (Eds.), International conference „Reforestation Challenges”. 03-06 June 2015, Belgrade, Serbia, Proceedings: Reforesta, 276.-281., Belgrade

- Burnie, G., L. Foulis, 2004: Botanica: The illustrated AZ of over 10,000 garden plants and how to cultivate them (No. Sirsi) i9783833112539.

- Buresti, E., M. Frattegiani, 1992: Mixed stands for high quality wood production. First results from an experimental plantation of pedunculate oak (Quercus robur) and Italian alder (Alnus cordata). Annali dell'Istituto Sperimentale per la Selvicoltura 23: 183.-199.

- Caudullo, G., A. Mauri, 2016: Alnus cordata in Europe: distribution, habitat, usage and threats. European atlas of forest tree 
species. Publications Office of the European Union, Luxembourg, ppe015443+.

- Chiti, T., G. Certini, A. Puglisi, G. Sanesi, A. Capperucci, C. Forte, 2007: Effects of associating a N-fixer species to monotypic oak plantations on the quantity and quality of organic matter in minesoils. Geoderma 138(1-2): 162.-169.

- Clark, J.R., G.E. Hemery, P.S. Savill, 2008: Early growth and form of common walnut (Juglans regia L.) in mixture with tree and shrub nurse species in southern England. Forestry 81(5): 631.644.

- Corazzesi, A., A. Tani, F. Pelleri, 2010: Effetto della consociazione e del diradamento in un impianto di arboricoltura da legno con latifoglie di pregio dopo oltre 20 anni dallimpianto. Annals of Silvicultural Research 36: 37.-48.

- Cutini, A., T. Giannini, 2009: Effetti della consociazione con Alnus cordata sulla funzionalità di impianti di noce comune (Juglans regia L.) sottoposti a diradamento. Forest@-Journal of Silviculture and Forest Ecology, 6(1): 29.-38.

- Devkota, N.R., P.D., Kemp, J. Hodgson I. Valentine, I.K.D Jaya, 2009: Relationship between tree canopy height and the production of pasture species in a silvopastoral system based on alder trees. Agroforestry systems 76 (2): 363.-374.

- Ducci, F., A. Tani, 2009: EUFORGEN Technical Guidelines for genetic conservation and use of Italian alder (Alnus cordata). Bioversity International: 1.-6., Italy, Rome

- Đurasovic, P., 1997: Unošenje egzotičnog drveća i grmlja na Dubrovačko područje. Šumarski list 121(5-6): 277.-289.

- Ettinger, J., 1892: Botaničkivrt kr. sveučilišta Franje Josipa I. u Zagrebu. Šumarski list 9-10: 409.-422.

- Innangi, M., T. Danise, F. d'Alessandro, E. Curcio, A. Fioretto, 2017: Dynamics of organic matter in leaf litter and topsoil within an Italian alder (Alnus cordata (Loisel.) Duby) ecosystem, Forests, 8(7), 240.

- Karavla, J., 1994: Dendrološka i šumsko-uzgojna važnost starih parkova u Samoboru. Šumarski list 7-8: 221.-223.

- Krüssmann, G. (1984): Manual of cultivated broad-leaved trees and shrubs. Vol. 1. B-T Batsford, London

- Loewe, V., A. Álvarez, L. Barrales, 2013: Growth development of hardwood high value timber species in central south Chile, South America. In: 4th International Scientific Conference on Hardwood Processing 2013, Vol. 1, No. 2: 50.-61.

- Marković, J., N. Živanov, 1980: Osvrt na razvoj topola na Bokanjačkom blatu kod Zadra. Topola 125-126, Institut za topolarstvo, 44.-47., Novi Sad
- Mattheck, C., H. Breloer, 1994: Field guide for visual tree assessment (VTA). Arboricultural Journal 18(1): 1.-23.

- Mirković, D., 1975: Zapreminske tablice za johu na Deliblatskom pesku. Deliblatski pesak, Zbornik radova III, Dokumentacija za tehniku i tehnologiju u Šumarstvu broj 75. Jugoslovenski poljoprivredno šumarski centar, Beograd, Šumsko industrijski kombinat Pančevo: 135.-145., Beograd

- Mitchell, A. 1979: Die Wald-und ParkbäumeEuropas. Verlag Paul Parey, Hamburg und Berlin

- Praciak, A., N. Pasiecznik, D. Sheil, M. van Heist, M. Sassen, C. S. Correira, C. Dixon, G. Fyson, K. Rushforth, C. Teeling, editors, 2013: The CABI encyclopedia of forest trees. CABI, Oxfordshire, UK.

- Pretzsch, H., 2009: Forest dynamics, growth, and yield. In: Forest Dynamics, Growth and Yield, Springer: 1.-39., Berlin, Heidelberg.

- Russel, T., C. Cutler, M. Walters, 2007: Trees of the World: An Illustrated Encyclopedia and Identifier. Hermes House.

- Shaw, K., B. Wilson, S. Roy, 2017: Alnus cordata. The IUCN Red List of Threatened Species2017:e.T194657A117268007.http:// dx.doi.org/10.2305/IUCN.UK.2017- 3.RLTS. T194657A117268007.en

- Tani, A., A. Maltoni, B. Mariotti, 2006: Gli impianti da legno di Juglans regia realizzati nell'area mineraria di S. Barbara (AR). Valutazione dell'effetto di piante azotofissatrici accessorie. Forest@-Journal of Silviculture and Forest Ecology, 3(4): 588. -597.

- Testaferri, G., E. Bianchetto, C. Bidini, M. Terradura, F. Pelleri, 2019: Confronto tra differenti schemi e densità d'impianto in piantagioni a prevalenza di rovere (Quercus petraea [Matt.] Liebel.): uncaso di studio in Umbria. Forest@-Journal of Silviculture and Forest Ecology 16(1), 40.-47.

- Turok, J., G. Eriksson, J. Klenischmit, S. Canger, 1996: Noble hardwoods network: Report of the $1^{\text {st }}$ meeting, 24-27 March 1996, Escherode, Germany, International Plant Genetic Resources Institute, Rome, Italy

- Tomić, Z., 2013: Natural forest communities of Fruška Gora national park in light of the latest syntaxonomical and ecosystem principles. Hrvatska misao, Br. 1 (61), nova serija sv. 46. Matica Hrvatska Sarajevo: 25-42, Sarajevo.

- Vidaković, M., 1986: Arboretum Lisičine. ROŠ „Slavonska šuma" Vinkovci: 1.-87., Zagreb

- ${ }^{* *}$ Republički hidrometeorološki zavod Srbije: http://www.hidmet.gov.rs/ciril/meteorologija/stanica_sr. php?moss_id=13274

\section{SAŽETAK}

Analizirani su rast i struktura linijskog zasada talijanske johe (Alnus cordata /Loisel/ Duby) na Fruškoj gori (Srbija). Cilj ovoga rada je da ukaže na elemente rasta i strukturu linijskog zasada talijanske johe u starosti 11 i 16 godina, i time doprinese upoznavanju adaptivnog i proizvodnog potencijala ove vrste u raspoloživom zasadu u Srbiji.

Zasad je osnovan dvogodišnjim sadnicama s međusobnim razmakom 7 m, odnosno sa 200 stabala po hektaru, na antropogeno izmijenjenom staništu lužnjaka i graba, na nadmorskoj visini $125 \mathrm{~m}$. Na temelju usporednog dendrometrijskog premjera 35 stabala u dobi 11 i 16 godina, dominantna visina iznosila je $15 \mathrm{i} 21 \mathrm{~m}$, a srednja visina po Loraju 13,4 i 19,5 m. Dominantni promjer iznosio je $32,4 \mathrm{~cm} \mathrm{u} 11$. godini, a 59,4 cm u 16. godini, dok je srednji promjer iznosio $25,1 \mathrm{~cm}$ i $47 \mathrm{~cm}$. Na te- 
melju izračuna da se po hektaru nalazi 200 stabala u 11. godini temeljnica je iznosila blizu $10 \mathrm{~m}^{2} \cdot \mathrm{ha}^{-1}$, a volumen preko $100 \mathrm{~m}^{3} \cdot \mathrm{ha}^{-1}$, a u 16. godini temeljnica je iznosila blizu $35 \mathrm{~m}^{2} \cdot \mathrm{ha}^{-1}$, a volumen preko $300 \mathrm{~m}^{3} \cdot \mathrm{ha}^{-1}$ (Tablica 1). Debljinska struktura stabala u zasadu je unimodalna u obje životne dobi (Tablica 2, Slika 1), a visinska struktura iskazana grupiranjem visina u stupnjeve širine $3 \mathrm{~m}$, ima opadajući oblik u 11. godini i zvonasti unimodalni oblik u 16. godini (Tablica 3, Slika 2). Parametri modela ovisnosti visina stabala o njihovim početnim prsnim promjerima i značajke njegove ocjene ukazuju da se u dobi 11 godina 55\% varijabilnosti visina može pripisati njihovim prsnim promjerima, dok je u dobi 16 godina ovisnost manje izražena (Tablica 3, Slika 3). Stupanj vitkosti opada sa starošću. U dobi 11 godina stupanj vitkosti je bio u rasponu 38-79, prosječno 54, a u dobi 16 godina u rasponu je 31-64, prosječno 43 (Tablica 4, Slika 4). U razdoblju od 11. do 16. godine tečajni prirast promjera iznosio je $4,4 \mathrm{~cm} \cdot \mathrm{god}^{-1}$, visine $1,22 \mathrm{~m} \cdot \mathrm{god}^{-1}$, a temeljnice i volumena po hektaru $4,9 \mathrm{~m}^{2} \cdot \mathrm{ha}^{-1} \cdot \operatorname{god}^{-1}$ i $39,6 \mathrm{~m}^{3} \cdot \mathrm{ha}^{-1} \cdot \operatorname{god}^{-1}$ (Tablica 6). Oblik raspodjele tečajnog prirasta prsnih promjera, temeljnice i volumena stabala je sličan, sa slabo izraženom desnom asimetrijom i platikurtičnim rasporedom, a tečajni prirast visina stabala karakterizira izražena lijeva asimetrija $\mathrm{i}$ neizražen platikurtični raspored. U razdoblju 11.-16. godine stupanj vitkosti se prosječno smanjuje za veličinu 2,25 godišnje, uz raspon od $0,68-4,10$ (Tablica 7). Zavisnost tečajnih prirasta promjera, temeljnice i volumena o njihovim početnim veličinama u 11. godini dobro opisuje linearni model, gdje se $50-70 \%$ varijabliteta može pripisati njihovim početnim veličinama. Tečajni prirast visina nije uvjetovan nihovim visinama u dobi 11 godina. Međutim, promjena stupnja vitkosti u razdoblju 11-16 godina ima jasno izražen negativan linearan trend, odnosno stabla s većim stupnjem vitkosti u dobi 11 godina također su imala i veći pad (Tablica 8). Uz sva ograničenja za generalizaciju zaključaka zbog malog uzorka stabala i linijskog zasada značajke rasta u 11. i 16. godini dobi ukazuju da talijanska joha ima karakteristike brzog rasta i može predstavljati potencijalno primjenjivu vrstu u sličnim područjima.

KLJUČNE RIJEČl: Alnus cordata (Loisel) Duby, introdukcija, visinska i debljinska struktura, prirast. 